\title{
BOLSONARO AND BRAZIL'S ILLIBERAL BACKLASH
}

\author{
Wendy Hunter and Timothy J. Power
}

forthcoming in Journal of Democracy 30, no. 1 (2019)

accepted for publication on 12 December 2018

Wendy Hunter is professor of government at the University of Texas at Austin. Her works include The Transformation of the Workers' Party in Brazil, 1989-2009 (2010). Timothy J. Power is head of the Oxford School of Global and Area Studies and professor of Latin American politics at the University of Oxford. Most recently, he is coauthor of Coalitional Presidentialism in Comparative Perspective: Minority Presidents in Multiparty Systems (2018).

On 28 October 2018, Brazilian voters delivered a sweeping victory to presidential candidate Jair Bolsonaro, putting the far-right populist at the helm of the world's fourth-largest democracy. After a raucous campaign in which the former army captain demonized his political opponents and promised to save the country from total ruin, Bolsonaro handed a stinging defeat to the left-leaning Workers' Party (PT), which had governed Brazil from 2003 to 2016. Social media, along with networks of Pentecostal churches, helped to disseminate Bolsonaro's incendiary messages and organize his broad multiclass following.

After nearly clinching the presidency in the October 7 first round with over 46 percent of valid votes, Bolsonaro received 55.13 percent of the vote in the runoff (see Table on $p$. XXXX). The remaining 44.87 percent went to PT candidate Fernando Haddad — a last-minute substitute during the first round for popular former president Luiz Inácio Lula da Silva, who had been imprisoned since April 2018 on corruption charges linked to Brazil's mammoth Operação Lava Jato (Operation Car Wash) scandal. In keeping with the polarizing tone of the campaign, the share of voters who cast ballots for each candidate closely approximated the share with a strong antipathy toward the opposing candidate. Concurrent elections for the 513-member Chamber of Deputies, the lower house of the bicameral National Congress, saw a surge by Bolsonaro's hitherto minuscule Social Liberal Party (PSL): This party went from 
winning only a single seat in 2014 to claiming 52 seats and the highest share of popular votes in 2018. Bolsonaro had joined the PSL — previously one of the nondescript "parties for rent" that help to populate Brazil's fluid system - in 2018 merely to qualify for a place on the presidential ballot.

The dramatic ascent of this far-right fringe figure and longtime legislative backbencher caught many by surprise. Brazilian presidential elections since 1994 had been marked by a virtual duopoly, with the left-leaning PT and the center-right Party of Brazilian Social Democracy (PSDB) as the predictable finalists. Taken together, these two parties consistently won between 70 and 90 percent of the vote. The three presidents elected in this period - Fernando Henrique Cardoso (1995-2003) of the PSDB, followed by Lula (2003-11) and his chosen successor Dilma Rousseff (2011-16) from the PT-had all won second terms in office, lending an air of seeming stability to party politics.

Yet viewed in the context of the multiple crises afflicting Brazil since 2013, travails for which Brazilians widely blame the establishment parties, the Bolsonaro backlash begins to make sense. The once-formidable PT, which had won four consecutive presidential contests, was blamed for the serious downturn in the economy after 2013; the massive corruption scheme uncovered by the Lava Jato investigation, ongoing since 2014; and the unprecedented levels of crime on the streets of Brazil. Lula, the PT's standard bearer since 1980 , might have been able to overcome these inauspicious circumstances and carry the day. In fact, he was the front-runner in the polls until being disqualified at the end of August 2018 due to his corruption conviction. His popularity as a candidate, however, depended critically on his strong base of personal support (lulismo), which was much broader than partisan support for the PT (petismo). ${ }^{1}$ With Lula out of the mix, all the PT's "baggage," together with

\footnotetext{
${ }^{1}$ See Wendy Hunter, The Transformation of the Workers' Party in Brazil, 1989-2009 (New York: Cambridge University Press, 2010).
} 
its choice to nominate Lula's understudy at the eleventh hour, ultimately left the party unable to draw enough center-left support to elect Fernando Haddad. ${ }^{2}$

At the same time, overwhelming popular rejection of incumbent president Michel Temer tainted the two major center-right parties associated with his government: the PSDB and Temer's own Brazilian Democratic Movement (MDB, known until December 2017 as the Party of the Brazilian Democratic Movement, or PMDB). Temer, Rousseff's vicepresident from 2011 to 2016, assumed the presidency in the wake of her controversial impeachment. His ongoing and unsuccessful struggle to turn around the economy, defend himself against charges of malfeasance, and control crime in Brazil's major cities kept his approval ratings low and discredited the parties that supported him. It did not help that the PSDB nominated as its candidate a bland establishment figure, four-term São Paulo governor Geraldo Alckmin (who had lost badly to Lula in 2006). In the 2018 first round, Alckmin took less than five percent of the vote, while MDB candidate Henrique Meirelles, a former finance minister who ran on Temer's record, barely topped one percent. With the implosion of the MDB and PSDB, a broad political space from the center to the far right became vulnerable to a hostile takeover.

Bolsonaro seized the opportunity with gusto, sounding a "law and order" and anticorruption message that resonated strongly with the public. His emphasis on his role in the army under Brazil's former military dictatorship (1964-85) enhanced his credibility as a strong leader who would come down hard on crime. In a country in which one out of three members of Congress was under either indictment or investigation for criminal activity, Bolsonaro's previous political insignificance proved a boon: Never having held (or even run for) executive office or party leadership had shielded him from opportunities to reap the fruits

\footnotetext{
${ }^{2}$ Third-time presidential contender Ciro Gomes of the Democratic Labor Party (PDT), to whom some looked during the first round for a center-left option not weighed down by the PT's badly damaged reputation, also floundered: For some voters he was too much of an establishment figure, and for others he was compromised by his loyal service as a minister in Lula's cabinet. He ended up with 12.47 percent of valid votes.
} 
of corruption. And while Bolsonaro offered little tangible proof of his professed commitment to open markets (much less his qualifications to preside over a major economy), Brazil's business community—at first dubious about the candidate's purported free-market conversion-later swung behind him when faced with the binary choice between Bolsonaro and the return of the statist PT. In the end, the meteoric rise of Brazil's next president was made possible by a combination of fundamental background conditions (economic recession, corruption, and crime), political contingencies (most notably, the weakness of rival candidates), and a shakeup in campaign dynamics produced by the strategic use of social media.

\section{A Multidimensional Crisis}

What we refer to as a "perfect storm" in Brazil broke due to at least four simultaneous crises: an economic crisis caused by a prolonged recession, a political crisis of rising polarization and falling trust in established parties, a corruption crisis brought to the fore by the Lava Jato investigation, and the deterioration of an already dismal public-security environment. Taken together, these four crises led to a plunge not only in government legitimacy — with the Temer administration growing massively unpopular over 2017-18 — but in regime legitimacy as well. Since 1985, Brazilian democracy had had its ups and downs, but never before had it performed so poorly for so long. ${ }^{3}$

The brutal recession spanning the Rousseff administration and Temer interregnum followed a protracted expansion of the Brazilian economy between 2004 and 2013. This growth was driven by the international commodities boom and buoyed by new domestic stimuli such as higher minimum wages and the advent of Bolsa Família (a family-welfare

\footnotetext{
${ }^{3}$ On the crisis period, see Peter R. Kingstone and Timothy J. Power, "A Fourth Decade of Brazilian Democracy: Achievements, Challenges, and Polarization," in Kingstone and Power, eds., Democratic Brazil Divided (Pittsburgh: University of Pittsburgh Press, 2017).
} 
initiative that has become the world's largest conditional cash-transfer program). The clouds began to darken in 2014, with the economic slowdown threatening Rousseff's reelection bid that year. She eventually prevailed by a margin of 3.28 percentage points over the PSDB's Aécio Neves, but had the election been held even a few weeks later, the sharply worsening economic indicators could have changed the outcome. Even then, hardly anyone foresaw what was coming next: the worst recession in Brazilian history. Over the next two years, nearly 8 percent of Brazil's GDP — a sum almost equal to the entire GDP of Peru—vanished into thin air. Rousseff's belated appointment of pro-austerity finance minister Joaquim Levy (who lasted eleven months in office) came too late to stop the bleeding. By 2017, Temer's first full year in office, misery was widespread. Unemployment had increased to a record 12.7 percent and underemployment affected an additional 23.8 percent of the economically active population. ${ }^{4}$ The end of the recession in 2017 was an imperceptible technicality, with the economy expanding less than 1 percent in that year.

Eroding support for the Rousseff government had been evident even before the full onset of economic contraction. In June 2013, street marches originating in opposition to a fare hike for São Paulo public transportation morphed into a nationwide protest movement that issued demands of all types, but focused mainly on corruption and the poor quality of public services. Although diffuse and disorganized, the protests put Rousseff on the defense. They also revealed two emerging trends: (1) a deepening sentiment of rejection and hostility toward the PT (known colloquially as antipetismo) ${ }^{5}$ and (2) the presence of a small but visible far-right fringe openly expressing nostalgia for the "order" and "clean government" of the military dictatorship. Both these trends would drive demonstrators to the streets again in

\footnotetext{
4 “Entre 2014 e 2017, desemprego cresceu mais em Santa Catarina e no Rio,” Agência IBGE, 10 April 2018, https://agenciadenoticias.ibge.gov.br/agencia-noticias/2012-agencia-de-noticias/noticias/20118-entre-2014-e2017-desemprego-cresceu-mais-em-santa-catarina-e-no-rio-de-janeiro.

${ }^{5}$ See David J. Samuels and Cesar Zucco, Partisans, Antipartisans, and Nonpartisans: Voting Behavior in Brazil (New York: Cambridge University Press, 2018).
} 
2016, when Rousseff was impeached on charges of violating federal budgetary laws. Against a backdrop of full-blown recession and daily street protests, Rousseff's large and heterogeneous cross-party alliance in Congress - surefootedly assembled by her mentor Lula a decade earlier — quickly fell apart. Legislators paid little heed to Rousseff's legal defense, and moved quickly to oust her: She was forced to relinquish the government to VicePresident Temer (PMDB) in May 2016 and was finally convicted and removed from office in August. The PT and the left viewed Rousseff's removal as a golpe (parliamentary coup d'état) and Temer's successor government as illegitimate.

The sharp rise in political polarization between 2013 and 2016 was visible at both the mass and elite levels. Street protests dominated the nation's TV screens, and Rousseff's impeachment—-featuring a naked intracoalitional betrayal led by Temer-showed the political class at its worst. As Temer prepared to serve out the final two-and-a-half years of Rousseff's second term, the political atmosphere could hardly have been more toxic.

The daily revelations from Lava Jato, the largest corruption investigation in the world, added fuel to the fire. Lava Jato initially focused on money laundering through auto service stations. As the operation expanded, however, investigators stumbled onto a much larger bribery and kickback scheme involving rigged bids by leading construction firms for contracts with Petrobras, Brazil's national oil giant, and the recycling into illegal campaign donations of the profits these firms made by overcharging. In its first four years (2014-18), Lava Jato produced nearly one-thousand arrest warrants and 125 convictions, with the guilty verdicts falling on politicians and private businesspeople alike. Although the investigation ensnared politicians from fourteen different political parties (including Eduardo Cunha, a powerful former PMDB speaker of the lower house), many of the most important names were linked to the PT. Lava Jato led to the jailing of several past PT party presidents and treasurers before finally reaching former president Lula himself, who was sentenced in 2017 to nine 
years in prison for accepting a bribe in the form of a beachfront apartment from the construction firm OAS. This initial sentence was increased to twelve years by a regional court in early 2018 and was later upheld by the Supreme Court. Lula's unsuccessful legal appeals were front-page news throughout 2018, and his eventual exclusion from the presidential race may have changed the course of history. Yet Lava Jato's impact on the election was not simply a "legal" question: Revelations of pervasive corruption hardened both antiestablishment and (fairly or not) antipetista sentiment within the electorate, eventually working to Bolsonaro's advantage.

Finally, alarming levels of violent crime and public insecurity were pivotal to the outcome of the 2018 campaign. In 2017, seventeen of the fifty most violent cities in the world were in Brazil. ${ }^{6}$ The preponderance of these were located in the country's north or northeast and formed part of drug transit routes. In that same year, 63,880 people were murdered in Brazil, up 3 percent from 2016, and the murder rate was 30.8 per 100,000 people - a figure that compares unfavorably even with homicide rates in Mexico. ${ }^{7}$ That everyday policing is largely a state-level responsibility in Brazil's federal system, and not within the purview of presidents except in emergency situations, was an academic point in the minds of most voters. Heightened fear of crime cut across socioeconomic as well as ideological lines, giving Bolsonaro another opportunity to build broad political support. In truth, his hardline "eye for an eye" discourse, combined with the view that human rights must be subordinated to public safety, was nothing new: Bolsonaro had virtually "owned" this policy space since the 1990 s.

In the tense climate of 2018 , however, such appeals struck a chord with the electorate. Affluent sectors were drawn to the "law and order" candidate despite their ability to afford

\footnotetext{
${ }^{6}$ Angelo Young, "The Most Dangerous Cities in the World," 24/7 Wall St., 11 July 2018, https://247wallst.com/special-report/2018/07/11/the-most-dangerous-cities-in-the-world-2/2. 7 Anuário Brasileiro de Segurança Pública 2018, www.forumseguranca.org.br/publicacoes/anuario-brasileiro-de-seguranca-publica-2018.
} 
private security measures such as armed guards, armored vehicles, and gated communities. Poorer segments, who not only lack access to such options but also typically reside in areas of greater crime, sought credible promises of protection as well. The widespread view that recent governments had failed to keep the public safe strengthened the appeal of a candidate who openly advertised his willingness to combat crime by restricting due process, lowering the age at which defendants could be charged as adults, loosening gun laws, and giving the police more autonomy as well as greater firepower.

These four simultaneous crises took a heavy toll on support for both the government and the regime. Latinobarómetro, an annual survey of citizens in eighteen Latin American countries, found that Brazil's government had the lowest approval rating of any among this group in 2017 and $2018 .{ }^{8}$ In both years, only 6 percent of respondents said they approved of the incumbent government (compared, for instance, to 18 percent in Mexico and 22 percent in El Salvador). Figures for regime legitimacy are similar. In 2018 Brazil came in dead last in Latin America in levels of satisfaction with the performance of democracy. Only 9 percent of those surveyed reported being satisfied, a drop of 40 percentage points when compared to 2010, the final year of Lula's government. As Figure 1 suggests, 2015 was an inflection point in Brazilians' support for democracy: The number of respondents who agreed that "Democracy is preferable to any other system of government" started to fall, while the view that "For people like me, it doesn't matter whether we have a democratic government or an authoritarian one" began gaining in popularity. Although Brazil has routinely ranked comparatively low in the region in satisfaction with democracy as measured by these indicators, the downward trend and the current absolute level of indifference and even skepticism toward democracy are alarming. Needless to say, this situation bodes poorly for

\footnotetext{
${ }^{8}$ Figures in this paragraph are drawn from "Informe Latinobarómetro 2018," 9 November 2018, www.latinobarometro.org.
} 
the chances of strong action by ordinary Brazilians to defend democratic norms under the next president, whose illiberal inclinations have been hidden in plain sight for thirty years.

\section{Enter Bolsonaro}

Prior to his spectacular presidential victory, Jair Messias Bolsonaro was neither an outsider nor an insider in Brazilian politics. After sixteen years as a cadet and paratrooper in the army, from which he retired as a captain, Bolsonaro was first elected to the Rio de Janeiro City Council in 1988. His original platform was mostly limited to improving military salaries and advocating for military families and veterans. Beginning in 1990, he was elected to seven consecutive terms as a federal congressman from the State of Rio de Janeiro, with his campaign rhetoric gradually broadening to encompass a comprehensive far-right agenda. His victories were consistently comfortable due to Brazil's use of open-list proportional representation with a high number of representatives per district (Rio has 46 seats in the lower house), a system that is friendly to niche candidates with strong personal followings. During this period Bolsonaro appeared acutely aware of his narrow base: He never attempted to run in a majoritarian election, such as those for mayor, governor, senator, or president.

Although this longtime officeholder was not truly an outsider, Bolsonaro's fringe status in national legislative politics meant that he was not much of an insider either. In the 1990s and 2000s, Bolsonaro became a well-known though irrelevant backbencher, building a reputation as a gaffe-prone extremist and a cartoonish foil for the left. His ability to provoke opponents and generate controversy was the stuff of legend, and even led to legal cases against him. In 1999, Bolsonaro called for President Fernando Henrique Cardoso to be shot by firing squad as a punishment for privatizations. Loud and intemperate, he insulted his legislative colleagues on a regular basis. He infamously stated that PT congresswoman Maria do Rosário Nunes was "not worth raping." In a 2011 interview with Playboy, Bolsonaro said 
that he "would be incapable of loving a homosexual son" and would prefer that his son "died in an accident" before "show(ing) up with some bloke with a moustache." In 2017, he claimed that quilombolas (residents of communities formed by descendants of escaped slaves) were "not even good enough for procreation." On national television during the 2016 impeachment of Dilma Rousseff, a feverish Bolsonaro dedicated his vote to the army intelligence officer who oversaw her torture when she was a political prisoner in 1970 . The list goes on and on. ${ }^{9}$

It is tempting to write off Bolsonaro's behavior as that of an unhinged provocateur, but over time he acquired both a highly committed following and a degree of influence among the broader electorate. His longtime view that human-rights activists "only defend the rights of criminals," however ludicrous, is overwhelmingly endorsed by the Brazilian public. ${ }^{10}$ His nostalgia for the $1964-85$ military regime began to gain traction among voters clamoring for safer streets and an end to corruption, finding particular resonance among those too young to be able to compare life under authoritarianism with their experiences of democracy. Moreover, Bolsonaro's crude and inflammatory speech during Rousseff's impeachment — which lasted less than two minutes — put him in the public eye at the perfect time, allowing him to surf the wave of rising anti-PT sentiment in the run-up to the 2018 election. Thanks to Bolsonaro's legions of followers on social media (to whom he is known as $O$ Mito, or "The Legend"), even those voters who had previously tried to ignore Bolsonaro could not escape his growing national presence.

\footnotetext{
${ }^{9}$ For English translations of these remarks, see Sam Meredith, "Who Is the 'Trump of the Tropics'? Brazil's Divisive New President, Jair Bolsonaro-In His Own Words," CNBC, 29 October 2018, www.cnbc.com/2018/10/29/brazil-election-jair-bolsonaros-most-controversial-quotes.html; Mariana Simões, "Brazil's Polarizing New President, Jair Bolsonaro, in His Own Words," New York Times, 28 October 2018. ${ }^{10}$ An April 2018 IPSOS poll of 1,200 Brazilians found that only 20 percent believed that human rights benefited victims, while 66 percent believed that they benefited criminals. See "Dois em cada três brasileiros acham que 'direitos humanos defendem mais os bandidos', diz pesquisa," BBC, 16 May 2018, www.bbc.com/portuguese/brasil-44148576.
} 
A full year before the 2018 election, Bolsonaro was already boasting 15 to 20 percent support in opinion polls. He and Lula were the only strong candidates in so-called "spontaneous mention" polling (in which respondents are asked how they intend to vote without initially being provided with the names of parties or candidates), showing the motivation and enthusiasm of their respective voter bases. Much like Donald Trump (another perennial noncandidate) in the United States two years earlier, Bolsonaro read the public mood well and chose the right year in which to finally throw his hat in the ring. He accepted the nomination of the minuscule PSL, over which he knew he would have full operational control. During the convention season in May and June, no major party nominated a novel or appealing candidate who could challenge Bolsonaro from the center-right. On the left, Lula, far more popular than his wounded PT, continued to lead in all major polls right up until his removal from the race. Under these circumstances, Bolsonaro's easiest path to the presidency lay in a runoff election in which he would face a candidate from the weakened PT — but not Lula himself. This is exactly the scenario he got.

Bolsonaro's actual participation in campaign activities was minimal. After going to two televised debates during the first round, he was stabbed in the lower abdomen while being carried on the shoulders of supporters in Juiz de Fora on September $6 .{ }^{11}$ Narrowly escaping death, he underwent several operations and never returned to the campaign trail (in a first for Brazil, there were no debates in the runoff election). The massive media attention given to the assassination attempt—a "hard news" event that fell outside of normal government regulation of candidate access to TV and radio- - helped to consolidate Bolsonaro's position as the leading anti-PT candidate. With the final exclusion of Lula on September 11 and his understudy Haddad's ascent to second place in the polls, the binary

\footnotetext{
${ }^{11}$ Preliminary investigations suggest that the attack was perpetrated by a mentally unwell individual acting alone.
} 
choice facing voters became clear, and Bolsonaro was able to secure support from an even wider swath of anti-PT voters.

Polling during the runoff campaign showed that he had solidified many of his strengths and limited some of his earlier weaknesses. By October 2018, Bolsonaro-long perceived as a misogynist - even managed to narrow the yawning gender gap that had plagued him throughout the year. The four best predictors of support for Bolsonaro were income, education, religious affiliation, and region of residence. Bolsonaro won among all income groups except for the poor and very poor: Haddad proved more popular among voters whose monthly earnings were less than two times the minimum wage. Not only did Bolsonaro run away with the vote of Brazil's "traditional" middle class (households earning more than ten times the minimum wage), he also prevailed among the so-called "new" middle classes, whose emergence is often credited to the economic growth and socialinclusion policies overseen by the PT. ${ }^{12}$ Education, which in Brazil is highly correlated with income, was also a major factor. Despite Bolsonaro's frequent contention that Brazilian universities are hotbeds of "leftist psychos" (esquerdopatas), he scored an overwhelming victory among college graduates.

He also took 70 percent of the votes of Pentecostal Christians, who now make up a quarter of the Brazilian electorate. During the campaign, tightly organized networks of Pentecostal pastors had provided a vital communications channel for Bolsonaro, who has successfully sought to attract Brazil's evangelicals. The new president still describes himself as a Catholic, but has an evangelical spouse and attends a Baptist church; in 2016, he underwent a public baptism in the Jordan River by a fellow politician who is an Assembly of God pastor. ${ }^{13}$ Finally, patterns of regional support were stark. Although he lost the poor

\footnotetext{
${ }^{12}$ See Timothy J. Power, "The Reduction of Poverty and Inequality in Brazil: Political Causes, Political Consequences," in Ben Ross Schneider, ed., New Order and Progress: Development and Democracy in Brazil (New York: Oxford University Press, 2016).

${ }^{13}$ See Chayenne Polimédio, "The Rise of the Brazilian Evangelicals," Atlantic, 24 January 2018.
} 
northeast to the PT, Bolsonaro performed spectacularly in the economically advanced states of the south and southeast and in the Federal District (Brasília). He received 68 percent of the vote in Rio de Janeiro and São Paulo, 70 percent in the Federal District, and 76 percent in Santa Catarina, all areas with high levels of human development. ${ }^{14}$ With the exception of the very poor and northeasterners, Brazil as a whole went heavily for Bolsonaro.

\section{A Changing Party Landscape}

Who were the main casualties of the October 2018 presidential election? Suffering the greatest setbacks were the PT, the PSDB, and the party system anchored since 1994 by these rival parties, a system that had helped to consolidate Brazilian democracy. Even before the 2018 campaign began, the weaknesses of all three were already evident.

To say that Bolsonaro's victory reflects poorly on the PT is an understatement. Leaving aside major failures in the areas of economic management and administrative probity, the party's defeat laid bare its tragicomic dependence on Lula. The mythical status of Lula within the PT-evident in the staunch support for his candidacy even after his conviction - came at the expense of cultivating new political leaders. As far back as 2010, the commanding role that Lula played in Rousseff's presidential nomination had foreshadowed this problem. Technocratic and severe, Rousseff had been Lula's energy minister (2003-05) and chief of staff (2005-10). She had never held elected office and had no independent following or sway within the PT, thus allowing Lula to preserve his influence after leaving office. More recently, Lula's insistence on remaining the PT's candidate in 2018 even once it appeared likely that he would be barred from running raised fundamental questions about the party’s organizational strength and capacity for evolution. Not even Lula's disqualification

\footnotetext{
${ }^{14}$ On regional trends, see Kiko Llaneras, "Bolsonaro divide o Brasil: arrasa nas cidades mais brancas e mais ricas," El País, 30 October 2018.
} 
could strike him from the PT's narrative: In a particularly graphic demonstration of the party's overreliance on the former president, PT electoral strategists arranged for Fernando Haddad to don a Lula mask at campaign appearances and filled the airwaves with the slogan, "Haddad is Lula. Lula is Haddad." Although Lula did ultimately manage to transfer much of his popularity to Haddad, it was too little, too late. In any event, the party's future strategy cannot rest on invoking the legendary leader's aura.

The 2018 results also revealed that the PT's competitiveness in presidential elections has become increasingly confined to Brazil's northeast. In his 2002 presidential bid, Lula was able to clinch an electoral majority in every Brazilian state but one. In 2006, he deepened his foothold in poor northeastern states but lost seven others, including the key state of São Paulo and several states in Brazil's south and center-west. ${ }^{15}$ In 2010, Rousseff held onto the PT's northeastern stronghold but lost three additional states outside the region, and her vote totals in 2014 followed a roughly similar pattern. Haddad's performance in 2018 was even more lopsided. Although he won every state in the northeast and two in the north, he failed to carry a single state outside those regions. For the first time ever, the PT lost its ability to command a majority in the populous state of Minas Gerais, which borders Rio de Janeiro and São Paulo. And in many states, the PT candidate's margin of loss was shockingly high. ${ }^{16}$ In short, the PT risks becoming a regional party. Moreover, even within the party's northeastern stronghold, support is uneven: Haddad did significantly better in poor rural areas. With crime at record levels in urban areas, he was able to carry only two northeastern capital cities. If the PT's narrative remains centered on Lula and its popularity confined to the northeast, its prospects in future elections will be limited. To regain its competitiveness, the PT will need

\footnotetext{
${ }^{15}$ Wendy Hunter and Timothy J. Power, "Rewarding Lula: Executive Power, Social Policy, and the Brazilian Elections of 2006," Latin American Politics and Society 49 (Spring 2007): 1-30.

${ }^{16}$ See map at https://www.bbc.com/news/world-latin-america-46013408.
} 
to make rebalancing its regional appeal a priority within a broader process of reflection and renewal.

The 2018 vote totals reflected even more poorly on the PSDB, the PT's principal rival in presidential elections from 1994 to 2014. In the six previous contests, the PSDB had secured on average almost 40 percent of the vote. Yet the party once headed by renowned intellectuals and technocrats who championed democracy and free-market reforms alongside redistributive social policies has now lost five straight presidential elections, with a particularly dismal showing in 2018. It secured only 29 seats in the Chamber of Deputies (down from 54 in 2014) and will control only three of 27 state governments. With its overdependence on São Paulo and with no promising young leadership emerging, the PSDB's days as a major national party appear numbered. The MDB, the PSDB's main partner in the Temer administration, has a questionable future as well. A perennial source of support for both PT and PSDB presidents, this center-right party had not run a presidential candidate of its own since 1994. In 2018, however, the beleaguered Temer enlisted his finance minister Meirelles to carry the government's banner. The outcome was disastrous, with the MDB floundering not only in the presidential race but in the Chamber as well: The size of its delegation dropped from 66 members in 2014 to 34 in 2018. Overall, the spectacular self-destruction of the center-right (PSDB and MDB) and the emergence of a new far-right option (the PSL) imply major changes for the party system. On the left side of the spectrum, however, there is still no alternative to PT hegemony.

With high turnover in both houses and the major parties losing seats, Brazil, which had set the world record for party-system fragmentation four years earlier, has now topped its own record. Candidates from 30 different parties (up from 26 in the previous session) were elected to fill the Chamber of Deputies. Nine similarly sized parties will hold between 28 and 39 seats apiece. Politicians representing 21 different parties (up from 17) were chosen to fill 
the 81 -seat Senate. Notwithstanding rules intended to lower the number of parties in Congress by disadvantaging smaller parties_-which will inevitably cause some partyswitching in early 2019 - this fragmentation will complicate the formation of Congressional coalitions conducive to efficient and effective governance. With a president perceived as an ideological extremist, a dose of gridlock could be salutary. Yet it could also be counterproductive, insofar as Bolsonaro may be tempted to find illiberal paths around routine institutional obstacles.

Jair Bolsonaro did not "come out of nowhere" to win the presidency. Rather, Bolsonaro has been hidden in plain sight during his thirty-year career as a fringe defender of the defunct military regime, an advocate of the lex talionis, and an antagonist of minorities and human-rights activists. His election was possible only because Brazilian democracy had done so much to clear a path for him. Four simultaneous crises-corruption, recession, polarization, and rising crime - paved the way, creating a favorable environment for an incendiary populist. Corruption allegations implicating a dozen political parties discredited the political class. Center-right forces allied with a tremendously unpopular interim government imploded, leaving vacant a wide ideological space for Bolsonaro to fill. The PT clung to an imprisoned former president, opting for a strategy of victimization and drawn-out legal theater rather than providing early backing to the creditable Fernando Haddad. Door after door was flung open wide for Bolsonaro.

In the end, Bolsonaro won the election by successfully exploiting two major cleavages in the Brazilian electorate. One was the antiestablishment cleavage, centering on a widespread sentiment of cumulative disgust with politics and politicians as whole ("throw the rascals out"). The other was the anti-petista cleavage, which hinged on the determination among many voters to inflict a belated punishment on the party that had governed for over a decade (although the PT was no longer the incumbent party in 2018, it was treated as if it still 
were). Some candidates were on the winning side of one of these cleavages but not the other: Center-right candidates Alckmin and Meirelles, for instance, were anti-petistas but (lethally for them) card-carrying establishment insiders. Bolsonaro was the only candidate who was on the right side of both cleavages. He energized voters who detested the PT, and he energized voters who detested everyone. When the electoral options were narrowed to Bolsonaro and a petista whose name was not Lula, Bolsonaro won by a landslide.

The dynamics of the 2018 election have thus given Bolsonaro a strong popular mandate. Public expectations for bold and energetic action from the president are high. The multiple crises that first opened the door to Bolsonaro will linger, strengthening his position. In 2019, he will stand virtually alone at the apex of national politics: There is no single leader or party with the authority to effectively challenge him. The once-formidable PT is diminished and the PSDB is a shadow of its former self. Not only does Brazil lack a natural "leader of the opposition," it lacks a popular former president who is not in jail. Together with the polarized atmosphere and Bolsonaro's deeply illiberal inclinations, these opposition weaknesses have worrisome implications for Brazilian democracy.

Much like his populist predecessor Fernando Collor (president from 1990 until his impeachment and resignation in 1992), Bolsonaro lacks an institutionalized party to catch his falls and see him through hard times. As Collor's short-lived presidency showed, early public support is no substitute for a strong and enduring party base. In dealing with the country's perennially fragmented legislature, Bolsonaro will be, mathematically speaking, a minority Brazilian president like any other. His PSL, dominated by inexperienced newcomers elected on his coattails, will make up 10 percent of the Chamber of Deputies and less than 5 percent of the Senate. Even anticipated support from the usual "parties for rent" may not yield the coalition necessary to effectively confront the problems he has pledged to solve. To make good on his bold promises and maintain his "heroic" image, Bolsonaro is likely to resort to 
decree authority, and perhaps to plebiscitary initiatives as well. As a former paratrooper who exalts the military and is widely popular among police officers, Bolsonaro could also pivot to the security sector. His choice of the blustery former general Hamilton Mourão as his vicepresidential running mate suggests plans to cultivate this power resource. As of this writing in December 2018, he has already named seven current or former military officers to his cabinet, one of whom will head the Ministry of Defense (created in 1999 with the explicit intent of advancing civilian supremacy over the armed forces). To put this in perspective, none of the five military presidents in the dictatorship of 1964-1985 included more than seven officers in their cabinets. Drawing on the military for protection, if not actively deploying it to shore up his power, would represent a significant break with the last five Brazilian presidents, all civilians who had opposed the military regime.

Given the complex challenges Bolsonaro will encounter in trying to reverse Brazil's economic decline (an endeavor that will require him to take up the difficult task of pension reform), he is likely to view anticrime and public-security projects as a more promising route to quick and visible progress. Unleashing the police and even deploying the army in urban areas, which Temer has already done in Rio de Janeiro since February 2018, is a form of lowhanging fruit. By expanding these interventions, Bolsonaro could boost his approval on a crucial issue that matters to the public. Given the tremendous popularity that President Rodrigo Duterte of the Philippines has managed to secure by playing these cards, it would not be surprising if Bolsonaro followed suit, imperiling human rights and the rule of law in the process. 
Tables and Figures to Appear in Article

\begin{tabular}{|c|c|c|}
\hline Candidate (Party) & $1^{\text {st }}$ Round & Runoff \\
\hline Jair Bolsonaro (PSL) & 46.03 & 55.13 \\
\hline Fernando Haddad (PT) & 29.28 & 44.87 \\
\hline Ciro Gomes (PDT) & 12.47 & - \\
\hline Geraldo Alckmin (PSDB) & 4.76 & - \\
\hline João Amoedo (Novo) & 2.50 & - \\
\hline Cabo Daciolo (Patriota) & 1.26 & - \\
\hline Henrique Meirelles (MDB) & 1.20 & - \\
\hline Marina Silva (Rede) & 1.00 & - \\
\hline Other Candidates (5) & 1.50 & - \\
\hline Totals & 100.00 & 100.00 \\
\hline
\end{tabular}

Source: Tribunal Superior Eleitoral, hitp://www. Ise.jus.br. 


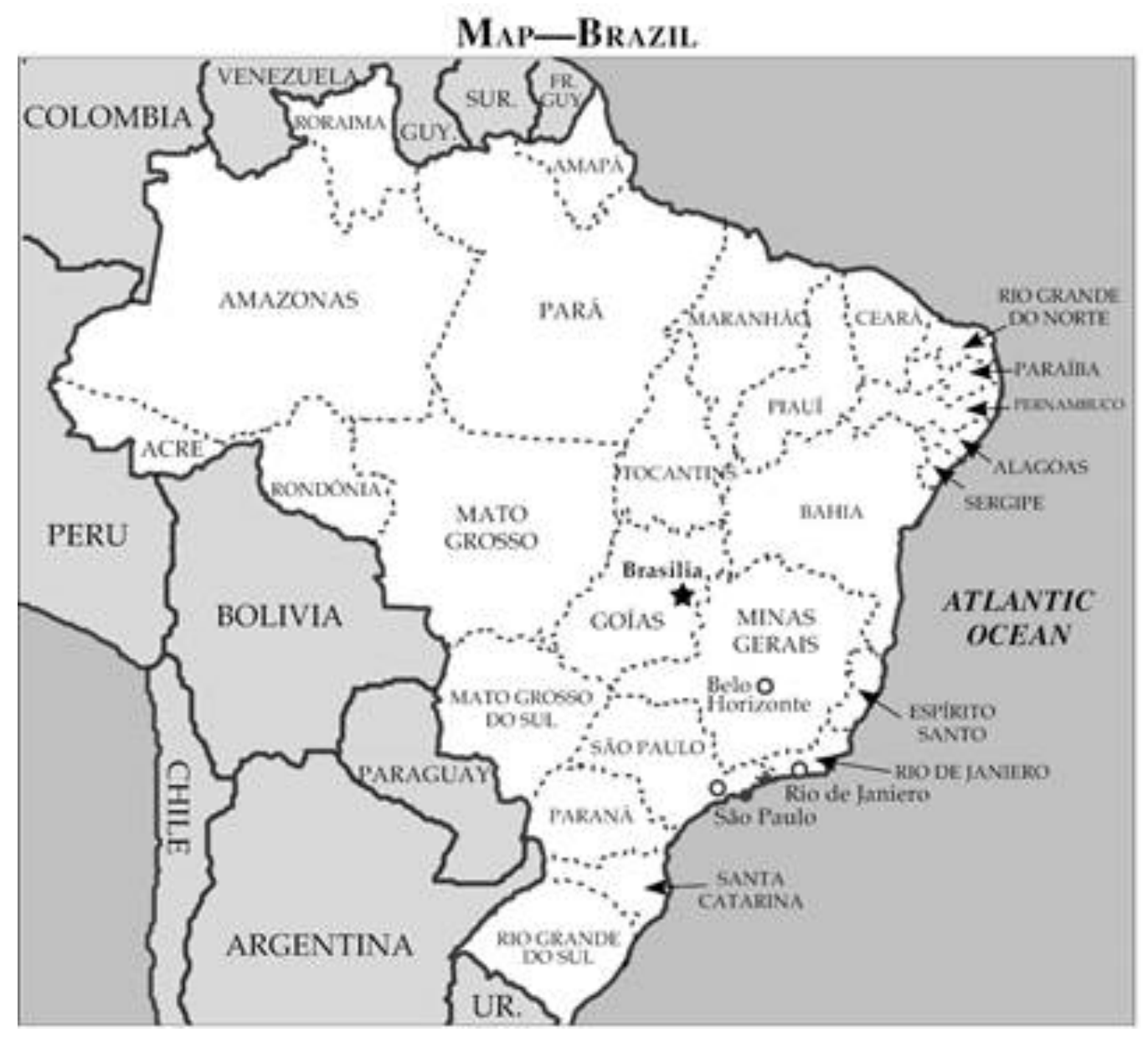


Figure 1-Brazilian GDP Growth, 2003-2019 (\%)

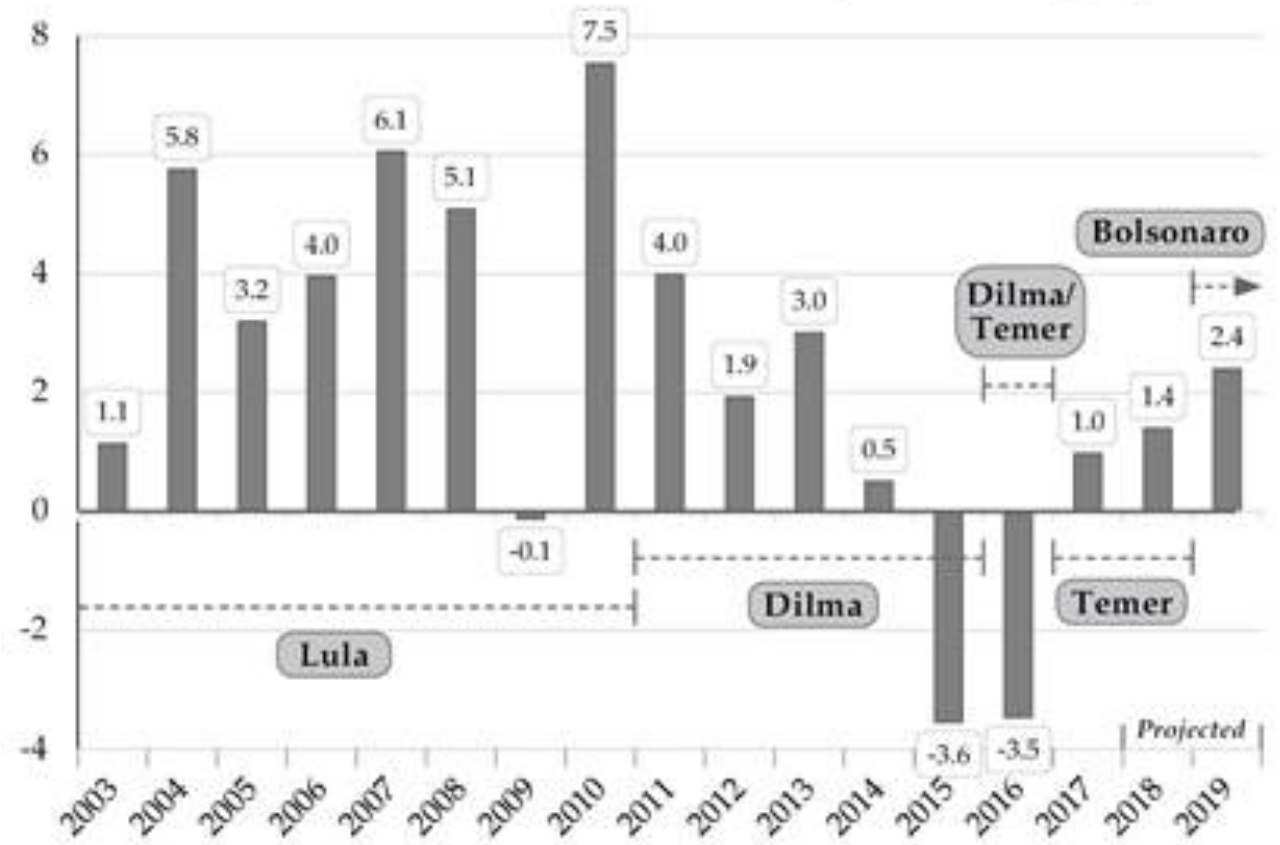

Sources: Data for 2003-2017 are from the World Bank (dafaworldbank.org). Data for 2018 and 2019 are projections made in September 2018 by the Central Bank of Brazil (แงเพ.bcb.gov,br). 


\section{Figure 2-Popular Support for Democracy in Brazil, 1995-2018 (Three-Year Moving Average, \%)}

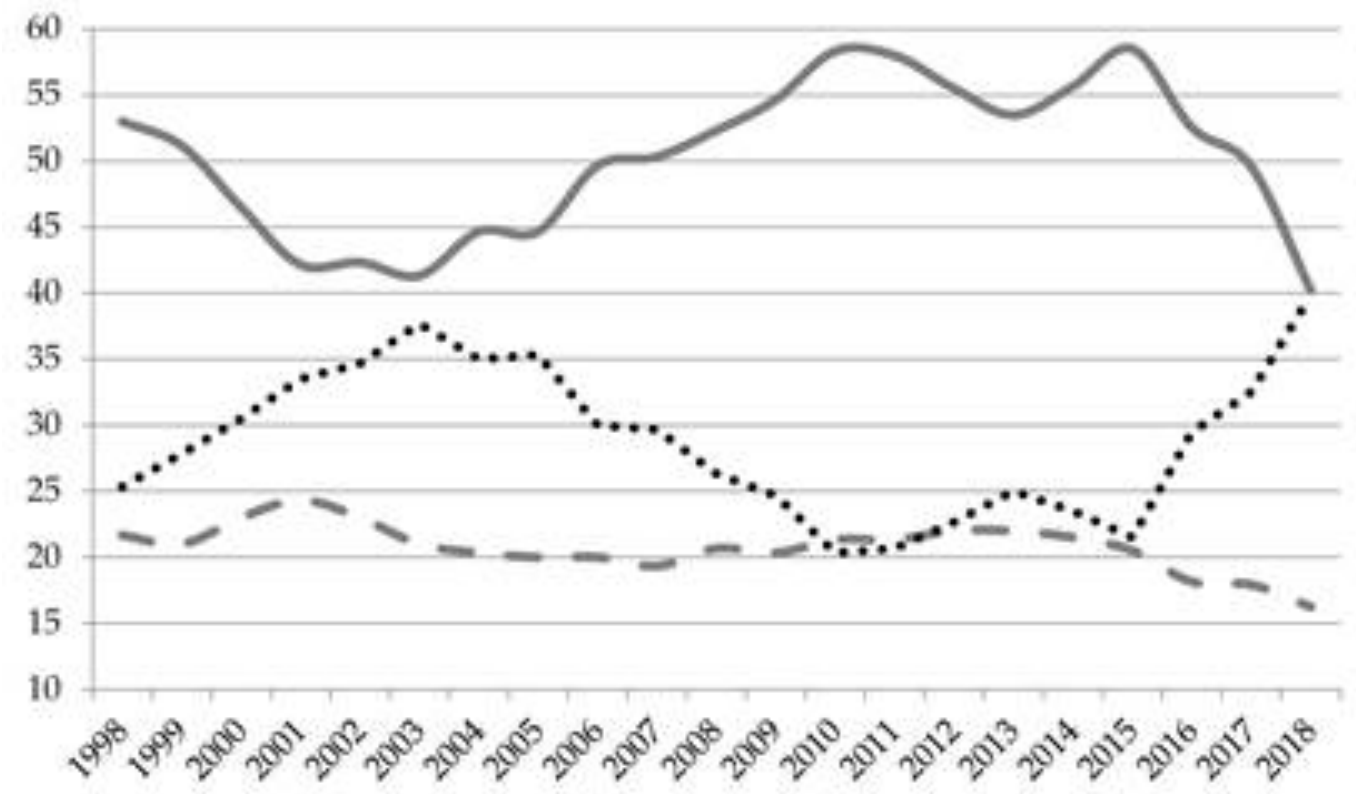

$$
\begin{aligned}
& \text { Democracy always preferable } \\
& \text { - - Under some circumstances, authoritarianism } \\
& \ldots \text {... For people like me, doesn't matter }
\end{aligned}
$$

Notes: Response options were "Democracy is preferable to any other system of government"; "Under some circumstances, an authoritarian government might be preferable to a democratic one", and "For people like me, it doesn"t matter whether we have a democratic government of an authoritarian one." Each annual value corresponds to the average of that year and the previous two years.

Source: www:latinobarometro.org. 